\title{
A child with Imerslund-Gräsbeck syndrome concealed by co-existing a-thalassaemia presenting with subacute combined degeneration of the spinal cord: a case report
}

Visvalingam Arunath ${ }^{1 *}$ (D) Thabitha Jebaseeli Hoole ${ }^{1} \mathbb{D}$, Asanka Rathnasri ${ }^{1} \mathbb{D}$, Oshanie Muthukumarana ${ }^{1}$, Ishara Minuri Kumarasiri ${ }^{1}$, Nishadi Dananjani Liyanage ${ }^{1}$, Yasintha Costa ${ }^{1}$ and Sachith Mettananda ${ }^{1,2}$ (D)

\begin{abstract}
Background: Imerslund-Gräsbeck syndrome is a rare genetic disease characterised by vitamin $\mathrm{B}_{12}$ deficiency and proteinuria.

Case presentation: A 4-year old Sri Lankan boy presented with gradually worsening difficulty in walking for two weeks duration. He was previously diagnosed and managed as having non-transfusion-dependent a-thalassaemia based on the presence of hypochromic microcytic anaemia, haemoglobin $\mathrm{H}$ inclusion bodies in the blood film and compound heterozygous a-thalassaemia genotype with a gene deletion. However, his transfusion requirement increased over the past three months and he gradually lost his motor developmental milestones during two weeks before admission. The neurological examination revealed generalised hypotonia, exaggerated knee jerks and extensor plantar response. His complete blood count showed pancytopenia, and bone marrow biopsy revealed megaloblastic changes. Serum vitamin $B_{12}$ and red blood cell folate levels were low. MRI revealed sub-acute combined degeneration of the spinal cord with characteristic 'inverted V sign'. Urine analysis showed non-nephrotic range proteinuria. The diagnosis of Imerslund-Gräsbeck syndrome was made due to the presence of non-nutritional vitamin $\mathrm{B}_{12}$ deficiency and asymptomatic proteinuria. He showed a rapid haematological and neurological improvement to intramuscular hydroxocobalamin.
\end{abstract}

Conclusions: This case report presents a rare occurrence of severe vitamin $B_{12}$ deficiency due to ImerslundGräsbeck syndrome masked by co-existent a-thalassaemia, resulting in serious consequences. It highlights the need for a high index of suspicion in evaluating children with severe anaemia, especially in the presence of mixed pathologies.

Keywords: Imerslund-Gräsbeck syndrome, Vitamin $B_{12}$, Thalassaemia, Inverted V sign, Subacute combined degeneration of the spinal cord, Megaloblastic changes, Hypopigmented hair, Anaemia

\footnotetext{
* Correspondence: arunkarthi91@gmail.com

${ }^{1}$ Colombo North Teaching Hospital, Ragama, Sri Lanka

Full list of author information is available at the end of the article
}

(c) The Author(s). 2021 Open Access This article is licensed under a Creative Commons Attribution 4.0 International License, which permits use, sharing, adaptation, distribution and reproduction in any medium or format, as long as you give appropriate credit to the original author(s) and the source, provide a link to the Creative Commons licence, and indicate if changes were made. The images or other third party material in this article are included in the article's Creative Commons licence, unless indicated otherwise in a credit line to the material. If material is not included in the article's Creative Commons licence and your intended use is not permitted by statutory regulation or exceeds the permitted use, you will need to obtain permission directly from the copyright holder. To view a copy of this licence, visit http://creativecommons.org/licenses/by/4.0/ The Creative Commons Public Domain Dedication waiver (http://creativecommons.org/publicdomain/zero/1.0/) applies to the data made available in this article, unless otherwise stated in a credit line to the data. 


\section{Background}

Imerslund-Gräsbeck syndrome is a rare genetic disease characterised by vitamin $B_{12}$ deficiency and proteinuria. Vitamin $B_{12}$ deficiency in children is usually diagnosed by the presence of macrocytic anaemia before the development of neurological complications. Here we report a child with severe vitamin $B_{12}$ deficiency due to Imerslund-Gräsbeck syndrome, whose haematological manifestations were masked by co-existing $\alpha$ thalassaemia for several years, ultimately presenting with neurological manifestations.

\section{Case presentation}

A 4-year old Sri Lankan boy presented with gradually worsening difficulty in walking and unsteadiness for two weeks duration. He was the first child of nonconsanguineous parents without a significant family history. He was investigated for anaemia since 18 months of age when he presented with haemoglobin of $8.0 \mathrm{~g} / \mathrm{dL}$, mean corpuscular volume (MCV) of $57.8 \mathrm{fL}$, mean corpuscular haemoglobin of $17.6 \mathrm{pg}$ and hypochromic microcytic red blood cells (RBC) in the blood film. His serum ferritin, serum iron and haemoglobin high-performance liquid chromatography were normal. Peripheral blood film showed haemoglobin $\mathrm{H}$ inclusion bodies, and the DNA analysis revealed a compound heterozygous state for $3.7 \mathrm{~kb} \alpha$-globin gene deletion and triplicated $\alpha$-globin genes $\left(-\alpha^{3.7} / \alpha \alpha \alpha\right)$. Complete blood counts of both parents were normal however, the $\alpha$-globin genotype of mother revealed $\alpha$-thalassaemia trait $\left(-\alpha^{3.7} / \alpha \alpha\right)$. He was managed as non-transfusion dependent $\alpha$-thalassaemia due to haemoglobin $\mathrm{H}$ disease with infrequent RBC transfusions and folic acid $1 \mathrm{mg}$ daily.
During 3-months preceding the current presentation, his haemoglobin level frequently dropped below $7 \mathrm{~g} / \mathrm{dL}$ thus requiring monthly blood transfusions. Then he started to lose motor developmental milestones in the two weeks before admission. At the time of admission, his gross motor development corresponded to the age of 9-12 months; he could sit unaided and stand with support, however, was not able to walk even with support. He was taking a normal balanced diet with food of both animal and plant origin and did not have any chronic illnesses.

On examination, the child had low mood, poor appetite, irritability and hypopigmented hair, which were of recent onset (Fig. 1a). His weight was $11 \mathrm{~kg}$ (at -3SD), and the growth chart showed weight loss of $2 \mathrm{~kg}$ over the past six months. His height was $92 \mathrm{~cm}$ (between $2 \mathrm{SD}$ to $-3 \mathrm{SD}$ ) and BMI was $12.9 \mathrm{~kg} / \mathrm{m}^{2}$ (between - 2SD to -3SD). There were multiple petechiae in the body. Neurological examination revealed generalised hypotonia, grade 4 muscle power in lower limbs and exaggerated knee jerk and extensor plantar response bilaterally. Examination of the upper limbs was normal except for hypotonia. Glasgow coma scale and intellectual functions were unaffected. Examination of other systems was normal.

His complete blood count revealed; haemoglobin- $6.8 \mathrm{~g} /$ dL, white cell count- $2800 / \mathrm{mm}^{3}$ (neutrophils- $9 \%$ and lymphocytes-89\%) and platelet- $53,000 / \mathrm{mm}^{3}$ (Table 1). Blood film showed pancytopenia and haemoglobin $\mathrm{H}$ inclusion bodies remained positive. His reticulocyte count was $0.6 \%$, and the bone marrow biopsy revealed mildly suppressed megaloblastic erythropoiesis with partial maturation arrest of RBC precursors. Granulopoietic progenitor cells were hypercellular with giant metamyelocytes (Fig. 2).

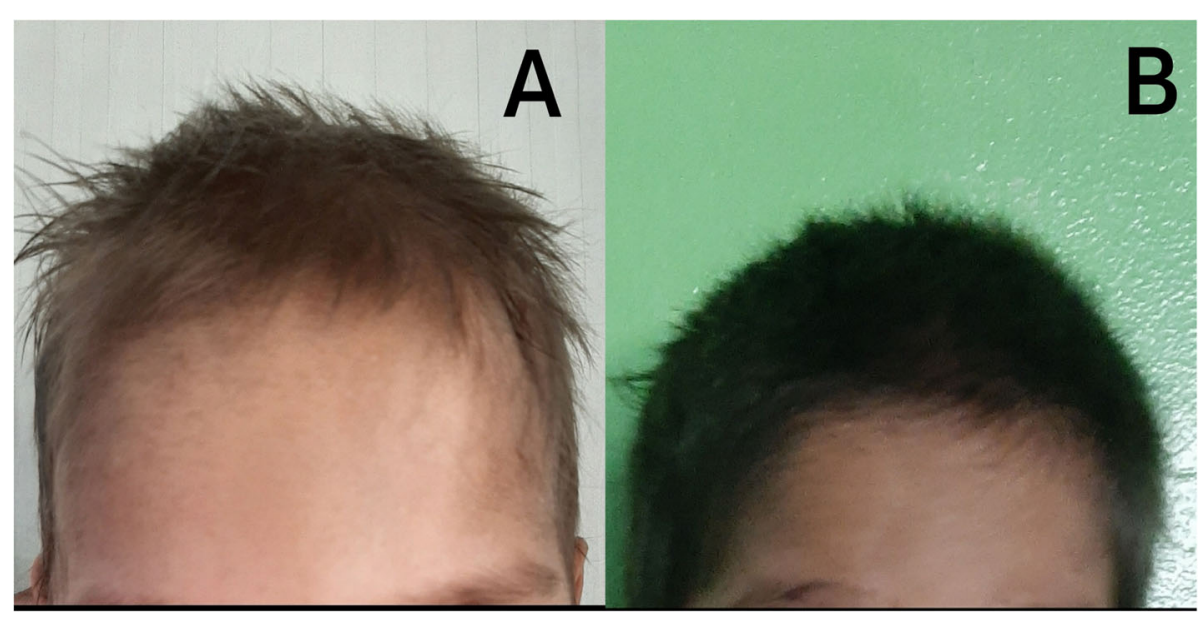

Fig. 1 - Photographs of the child taken on admission demonstrating hypopigmented hair (a) and eight weeks after commencing hydroxocobalamin treatment showing improvement in hair pigmentation (b) 
Table 1 - Haematological parameters before and after starting hydroxocobalamin treatment

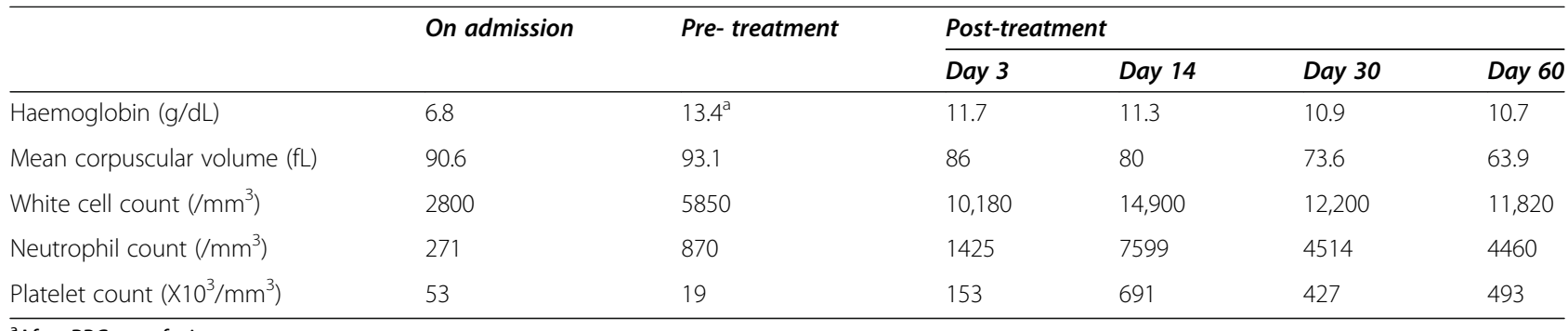

${ }^{a}$ After RBC transfusion

Based on the megaloblastic changes and neurological manifestations, vitamin $B_{12}$ deficiency was suspected. Subsequent investigations revealed; low serum vitamin $\mathrm{B}_{12}(116 \mathrm{pg} / \mathrm{ml}$; normal $187-883 \mathrm{pg} / \mathrm{ml})$ and $\mathrm{RBC}$ folate $(91 \mu \mathrm{g} / \mathrm{L}$; normal $126-650 \mu \mathrm{g} / \mathrm{L})$ levels. MRI of the spine revealed symmetrical T2-weighted high signal intensity in the posterior column from cervico-medullary junction to the 12th thoracic vertebra suggesting subacute combined degeneration of the spinal cord (Fig. 3). Axial T2weighted images showed 'inverted V sign' with symmetrical bilateral hyperintense signal in posterior columns (Fig. 4). MRI of the brain revealed multiple bilateral patchy T2-weighted high signal intensity in the centrum semiovale and deep white matter areas with mild cerebral and cerebellar atrophy. The ventricular system, extra-axial cerebrospinal fluid spaces and cerebellar folia were prominent. His nerve conduction study was normal, anti-intrinsic factor antibody titre was $14.7 \mathrm{U}$ (Normal $<20.0)$, and anti-parietal cell antibodies were negative. Urine analysis revealed urine albumin $2+$ with normal microscopy. Urine protein: creatinine ratio was $225 \mathrm{mg} / \mathrm{mmol}$ suggesting non-nephrotic range proteinuria. His liver and renal function tests, serum electrolytes, serum calcium, serum protein and renal ultrasonography were normal; however, 25-hydroxy vitamin D level was $27.3 \mathrm{ng} / \mathrm{mL}$ (normal 30-100 ng/mL).

Due to the presence of non-nutritional vitamin $B_{12}$ deficiency and proteinuria in the absence of renal pathology, the diagnosis of Imerslund-Gräsbeck syndrome was made. Genetic testing was not done due to its unavailability locally and difficulties in getting it done internationally. He was commenced on intramuscular hydroxocobalamin $1 \mathrm{mg}$ daily for two weeks followed by $1 \mathrm{mg}$ weekly for eight weeks and then $1 \mathrm{mg}$ monthly.

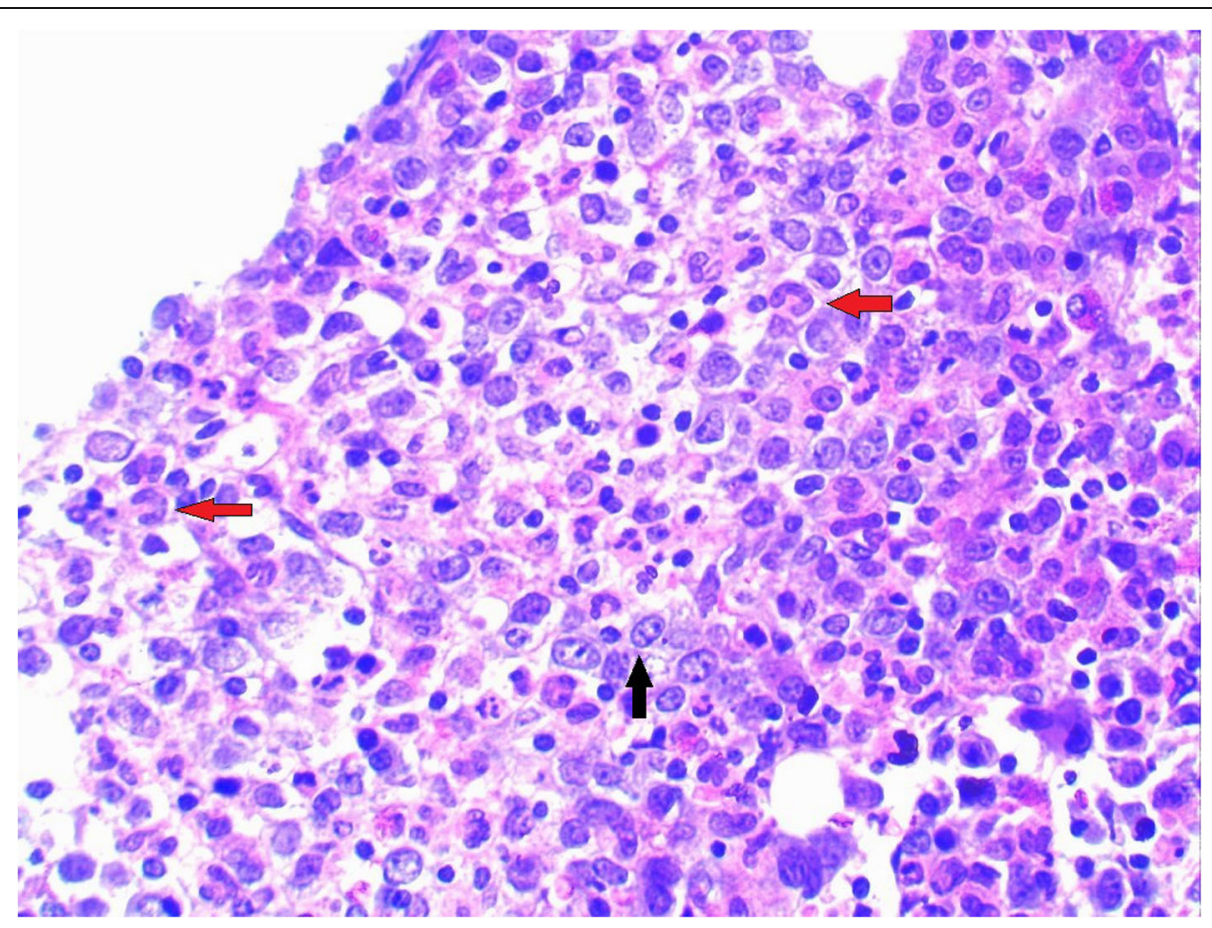

Fig. 2 - Bone marrow trephine biopsy showing megaloblastic erythropoiesis (black arrow) with multiple giant metamyelocytes (red arrows); haematoxylin and eosin stain 


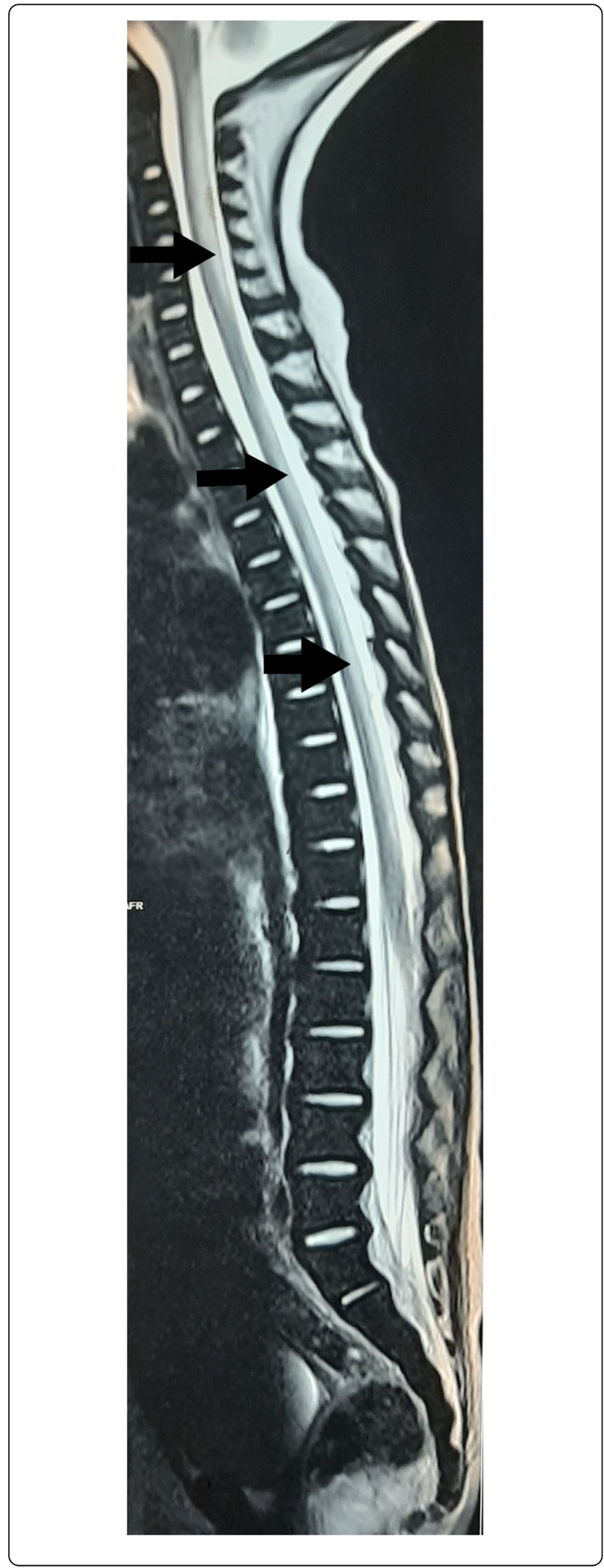

Fig. 3 - Sagittal T2-weighted MRI image showing increased signal intensity (arrows) in posterior columns of the spinal cord extending from cervico-medullary junction to the upper border of the T12 vertebra

With treatment, he demonstrated rapid improvement of general well-being, hair pigmentation, neurological functions, and haematological manifestations over $4-8$ weeks (Fig. 1b; Table 1). He could walk unaided after two weeks and was transfusion independent after two months.

\section{Discussion and conclusions}

Imerslund-Gräsbeck syndrome is an autosomal recessive genetic disease characterised by vitamin $B_{12}$ deficiency and proteinuria [1]. The primary pathology is selective malabsorption of vitamin $B_{12}$ due to a defect in the receptor for vitamin $\mathrm{B}_{12}$-intrinsic factor complex in the ileal enterocyte. Mutations in the cubilin gene $(C U B N)$ and amnionless gene $(A M N)$ which code for protein components of this receptor are known to cause Imerslund-Gräsbeck syndrome [2].

The deficiency of vitamin $B_{12}$ leads to haematological and neurological complications [3]. The classic neurological manifestations are due to subacute combined degeneration of the posterior and lateral columns of the spinal cord, which occur in long-standing deficiency. These manifestations are rare at present due to early recognition of vitamin $\mathrm{B}_{12}$ deficiency following

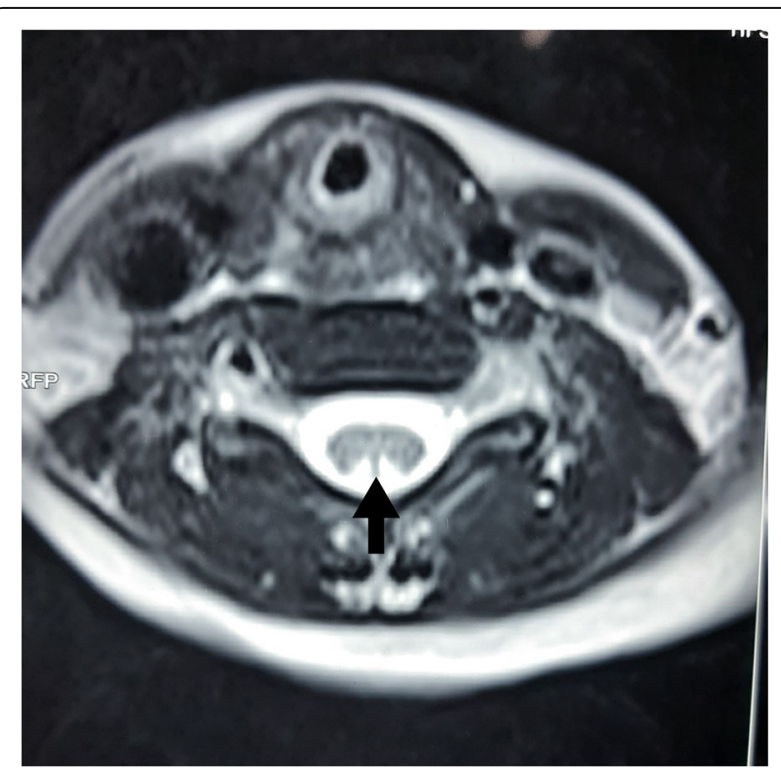

Fig. 4 - Axial T2-weighted MRI image showing symmetrical bilateral hyperintense signal in posterior columns; the characteristic 'inverted $\checkmark$ sign.' 
haematological manifestations that include macrocytic RBCs and megaloblastic anaemia.

Our patient was investigated for anaemia for over two years. Due to microcytic RBC and features of haemoglobinopathy with haemoglobin $\mathrm{H}$ disease, he was diagnosed to have haemoglobin $\mathrm{H}$ disease, a subtype of $\alpha$-thalassaemia. However, his $\alpha$-globin genotype showed deletion of one $\alpha$ globin gene that is consistent with a silent $\alpha$-thalassaemia carrier. So, blood smear should be normal. Also, very few haemoglobin $\mathrm{H}$ inclusion bodies may be rarely found in $\alpha$ thalassemia trait. Therefore, it is likely that his anaemia was not due to haemoglobin $\mathrm{H}$ disease but due to vitamin $\mathrm{B}_{12}$ deficiency of which the RBC phenotype was masked by the co-existent $\alpha$-thalassaemia trait.

The severe nature of vitamin $B_{12}$ deficiency in our patient despite normal dietary intake was suggestive of a genetic cause. The diagnosis of Imerslund-Gräsbeck syndrome was confirmed by demonstrating proteinuria and normal renal functions. Proteinuria is a recognised feature of Imerslund-Gräsbeck syndrome due to CUBN mutations. This is because cubilin plays an important role in the reabsorption of filtered albumin from proximal renal tubule [4]. In addition, mutations in $C U B N$ is associated with abnormal vitamin $\mathrm{D}$ metabolism due to the action of cubilin in the reabsorption of vitamin $\mathrm{D}$ binding protein from glomerular filtrate [5]. Our patient had low levels of 25-hydroxy vitamin D supporting the diagnosis of Imerslund-Gräsbeck syndrome due to CUBN mutation.

A review of the literature revealed few previous reports of patients with concurrent megaloblastic anaemia and thalassaemia and one patient with co-existing ImerslundGräsbeck syndrome and $\alpha$-thalassaemia [6, 7]. All these patients showed some features of macrocytic anaemia in the peripheral blood film, and none of them developed neurological manifestations. In contrast, blood film of our patient was compatible with $\alpha$-thalassaemia without macrocytosis. Therefore, the diagnosis was only made when the child presented with subacute combined degeneration of the spinal cord.

Another unusual feature in this child was the presence of hypopigmented hair. Although skin hyperpigmentation is a well-recognised dermatological manifestation of vitamin $B_{12}$ deficiency, the presence of hypopigmented hair is extremely rare with only a few previous reports $[8,9]$. The mechanism of this is still unclear; however, it is likely to be related to vitamin $B_{12}$ deficiency because it showed a rapid response to treatment.

This case report presents a rare association of ImerslundGräsbeck syndrome and $\alpha$-thalassaemia. It also highlights that vitamin $\mathrm{B}_{12}$ deficiency can be concealed by co-existent thalassaemia resulting in severe consequences. Therefore, a high index of suspicion is needed in evaluating a child with severe anaemia, especially in the presence of mixed pathologies.

\section{Abbreviations}

MCV: Mean corpuscular volume; RBC: Red blood cells; MRI: Magnetic resonance imaging; CUBN: Cubilin gene; $A M N$ : Amnionless gene

\section{Acknowledgements}

We acknowledge all the staffs who contributed to the management of this child, including University Paediatrics Unit of Colombo North Teaching Hospital, Department of Neurology and Department of Radiology, Lady Ridgeway Hospital.

\section{Authors' contributions}

All authors (VA, TJH, AMR, OM, IMK, NDL, YC and SM) contributed to the management of the patient. VA and SM involved in writing the manuscript. All authors read and approved the final manuscript.

\section{Funding}

Not applicable.

\section{Availability of data and materials}

Not applicable.

Ethical approval and consent to participate Not applicable.

\section{Consent for publication}

Written informed consent was obtained from the patient's parents for publication of this case report. A copy of the written consent is available for review by the Editor-in-Chief of this journal.

\section{Competing interests}

The authors declare that they have no competing interests.

\section{Author details}

${ }^{1}$ Colombo North Teaching Hospital, Ragama, Sri Lanka. ${ }^{2}$ Department of Paediatrics, Faculty of Medicine, University of Kelaniya, Ragama, Sri Lanka.

Received: 12 August 2020 Accepted: 10 January 2021

Published online: 18 January 2021

\section{References}

1. Gräsbeck R. Imerslund-Gräsbeck syndrome (selective vitamin B12 malabsorption with proteinuria). Orphanet journal of rare diseases. 2006 2006/05/19;1(1):17.

2. Tanner SM, Li Z, Bisson R, et al. Genetically heterogeneous selective intestinal malabsorption of vitamin B12: founder effects, consanguinity, and high clinical awareness explain aggregations in Scandinavia and the Middle East. Hum Mutat. 2004;23(4):327-33.

3. Stabler SP. Vitamin B12 Deficiency. New Engl J Med. 2013;368(2):149-60.

4. Birn H, Fyfe JC, Jacobsen C, et al. Cubilin is an albumin binding protein important for renal tubular albumin reabsorption. J Clin Investig. 2000; 105(10):1353-61

5 Nykjaer A, Fyfe JC, Kozyraki R, et al. Cubilin dysfunction causes abnormal metabolism of the steroid hormone $25(\mathrm{OH})$ vitamin $\mathrm{D}(3)$. Proceedings of the National Academy of Sciences of the United States of America. 2001; 98(24):13895-900.

6. RUSSO CL, HYMAN PE. OSEAS RS. Megaloblastic Anemia Characterized by Microcytosis: Imerslund-Grasbeck Syndrome With Coexistent a-Thalassemia. Pediatrics. 1988;81(6):875-6.

7. You JY, Chen CC, Lin EK, et al. The characteristics of megaloblastic anemia associated with thalassemia. Haematologica. 2002:87(5):550-1.

8 Noppakun N, Swasdikul D. Reversible hyperpigmentation of skin and nails with white hair due to vitamin B12 deficiency. Archives of dermatology. 1986;122(8):896-9.

9. Bhat RY, Varma CP. Reversible hypopigmentation of hair secondary to Vitamin B12 deficiency. Our Dermatol Online. 2013;4(1):101-2.

\section{Publisher's Note}

Springer Nature remains neutral with regard to jurisdictional claims in published maps and institutional affiliations. 